\title{
Structural features, labor conditions and family succession in dairy production systems in Paraná State, Brazil
}

\author{
Ferenc Istvan Bánkuti ${ }^{1}$, Júlio César Damasceno ${ }^{1}$, Sandra Mara Schiavi ${ }^{2, *}$, \\ Kellen Cristina Kuwaraha ${ }^{1}$ and Rodrigo César Prizon ${ }^{1}$ \\ 1 Animal Science Department, State University of Maringá (UEM), Maringá, Paraná, Brazil \\ 2 Business Department, State University of Maringá (UEM), Maringá, Paraná, Brazil
}

\begin{abstract}
Brazil is the fourth largest milk producer in the world. Besides its economic relevance, milk production has an important social function in Brazil. Dairy activity employs a large amount of people and contributes to regional development. But some drawbacks remain, such as poor labor conditions and problems for family succession. Labor conditions may be critical for successors to decide whether to remain in dairy activity. Paraná is the second largest milk producer in Brazil, mainly with smallholder family dairy systems. This paper aims to discuss labor conditions, family succession and structural features in Paraná's dairy activity. Our hypothesis is that family-based farms present poorer structure, poorer labor conditions and are less prone to family succession. The method comprised face-to-face interviews with 153 dairy farmers, in two groups: 117 family-based farms (Group 1) and 36 hired-labor farms (Group 2). Common factor analysis led to identify three factors: "structure", "labor conditions" and "individual conditions to family succession". Dairy farms in Group 1 present poorer structural and labor conditions, although being more prone to family succession, partially supporting our above hypothesis. Thus, structural features and labor conditions seem not to be the driving factors for the intent to family succession, which suggests the existence of other incentives. Results also indicate the need to improve labor conditions, especially for Group 1, since poor labor conditions may threaten family succession in the very long run. Efforts to improve family labor conditions are necessary to ensure long-term sustainability of dairy farming in Paraná State. Further studies could investigate social, market, technology and political features directing decision-making in family succession. Expanding the variables for labor conditions and structure, as well as including other social and behavioral factors, could put more light on the differences between dairy farms using and not using hired labor. Finally, a deeper investigation on reasons why family-based farmers do not promote better labor conditions is critical for the future of Paranás dairy sector.
\end{abstract}

Keywords: dairy production / work in agriculture / dairy farmers / factor analysis / farming systems

\begin{abstract}
Résumé - Caractéristiques structurelles, conditions de travail et succession familiale dans les systèmes de production laitière dans l'État du Paraná, Brésil. Le Brésil est le quatrième plus grand producteur mondial de lait. Le secteur laitier joue un rôle économique et social important, emploie un grand nombre de personnes et contribue au développement régional. Mais certains problèmes subsistent, comme les mauvaises conditions de travail et les problèmes de succession. Les conditions de travail sont cruciales pour que des successeurs décident ou non de reprendre l'exploitation. Le Paraná est le deuxième État producteur de lait au Brésil, principalement avec des petits systèmes laitiers familiaux. Cet article discute des conditions de travail, de la succession familiale et des caractéristiques structurelles dans les exploitations laitières familiales du Paraná. La méthode consiste en entrevues en face à face avec 153 producteurs laitiers de deux groupes: 117 systèmes de production employant seulement du travail familial (Groupe 1) et 36 systèmes de production employant du travail salarié (Groupe 2 ). Notre hypothèse est que les systèmes de production laitière familiaux présentent des structures moins adaptées, de moins bonnes conditions de travail et sont moins susceptibles d'être transmis par succession familiale. Une analyse factorielle commune a dégagé trois facteurs: «structure», «conditions de travail» et «conditions individuelles pour la succession familiale ». L'hypothèse est partiellement validée : les systèmes laitiers du Groupe 1 présentent
\end{abstract}

\footnotetext{
*Corresponding author: sandraschiavi@gmail.com
} 
de moins bonnes conditions structurelles et de travail, mais sont plus enclins à la transmission par succession familiale. Les caractéristiques structurelles et les conditions de travail ne semblent pas être des facteurs déterminants de l'intention de succession familiale, ce qui suggère que les producteurs laitiers ont d'autres motivations. Malgré l'intérêt des producteurs pour se maintenir dans l'activité, les résultats indiquent la nécessité d'améliorer les conditions de travail, notamment pour le Groupe 1, car de mauvaises conditions de travail menacent la succession familiale à long terme. L'amélioration des conditions du travail familial est nécessaire pour assurer la durabilité de l'élevage laitier au Paraná. Des recherches ultérieures pourraient examiner les caractéristiques sociales, commerciales, technologiques et politiques orientant la décision de succession familiale. L'augmentation du nombre des variables relatives aux conditions de travail et à la structure, ainsi que la prise en compte d'autres facteurs sociaux et comportementaux, pourraient éclairer les différences entre les systèmes laitiers utilisant ou n'utilisant pas de travail salarié. Des études sur les raisons pour lesquelles les producteurs laitiers familiaux ne promeuvent pas de meilleures conditions de travail sont essentielles pour l'avenir du secteur laitier du Paraná.

Mots clés : production laitière / travail en agriculture / producteur laitier / analyse factorielle / système d'exploitation agricole

\section{Introduction}

Agriculture plays a remarkable social and economic role worldwide (Robinson et al., 2014). However, many farmers are facing a new economic and market environment, imposing new challenges (Hansson and Ferguson, 2011). Among those, there is the lack of incentives for the youth to remain in activity. Brazil has been suffering with rural exodus along the years: eight million young people working in rural areas do not show intention to remain there (MDA, 2015), representing a social group with a migratory trend (Debres, 2014; Foguesatto et al., 2016; Matte et al., 2015a). Migration to urban centers may create social and economic problems, not only individually but also to territories. This might bring rural population aging and problems for new family formation (Matte and Machado, 2016; Matte et al., 2015a), among other consequences. Rural exodus has been more intense in family-based farming and main world food suppliers (Matte and Machado, 2016).

In Brazil, agribusiness is among the most dynamic and important economic sectors. Brazilian dairy sector has been of great economic importance, being the fourth largest milk producer in the world (USDA, 2015). Besides its economic relevance, milk production has an important social role (Oliveira and Silva, 2012). In 2006, Brazil accounted for 1.3 million dairy farms, of which $84 \%$ were family-based and generated income for more than four million people (IBGE, 2006; DIEESE, 2011).

Among Brazilian States, Paraná is the second largest milk producer, accounting for $14.1 \%$ of national production in 2016 (IBGE, 2015). Milk production comprises 115500 farmers in Paraná, being the fourth most important activity for familybased agriculture (Telles et al., 2008). Almost $85 \%$ of dairy farmers in Paraná are family-based (IBGE, 2006), and 55\% of dairy farmers in Paraná are smallholders producing less than 50 liters of milk per day (IPARDES, 2009). Dairy activity is responsible for regional positive externalities, contributing for regional development (Gomes and Ferreira Filho, 2007; Neto and Basso, 2005; Nicholson et al., 2011; Royer, 2011). Thus, family-based dairy activity seems to have an important economic and social role in Paraná State.
Despite its social and economic importance, some drawbacks remain in dairy activity, such as decision making on family succession. Family succession is considered the substitution of management and control activities in a production system of parents by children (Matte and Machado, 2016; Matte et al., 2015b). The decision on family farming succession is made from a set of structural variables in production systems (Leonard et al., 2017; von Thünen, 1966; Williamson, 1985), considering cognitive aspects and relational network (Ferguson and Hansson, 2013; Joosse and Grubbström, 2017; Morais et al., 2017).

When discussing the complexity of family farming, van der Ploeg (2010) points out that family's decision-making involves a coherent combination of material, relational, social and symbolic resources, at the farm level, and market, technology and government policies, at higher levels. In that sense, heterogeneity is an important element in family farming research. Many authors highlighted the importance of investigating farmer's decisions considering resources and farm and farmer's features (Hansson and Ferguson, 2011; Hitt and Tyler, 1991; Novo et al., 2012; ZúñigaVicente et al., 2005). In this sense, some authors defined structural farm aspects such as farm size, specialization degree and other technical features as important elements that affect the farmer's intention to remain on rural activity (Hansson and Ferguson, 2011; Zúñiga-Vicente et al., 2005). Other authors discussed some driven factors to farmer's decision making, such as educational level, experience in activity, human resources, farmer's social goals and intention to family succession (Brouthers et al., 2000; Hansson and Ferguson, 2011; Hitt and Tyler, 1991; Pietola et al., 2003). Thus, the decision to remain on dairy activity might be linked to material and immaterial resources, among those farm structure and intent to family succession.

Recent research indicates that dairy farming is hard work and does not provide desirable labor conditions, especially in family-based systems (Cavalheiro and Rempel, 2014; Dos Santos et al., 2012; Matte and Machado, 2016; Novo et al., 2012). Hard work is due to inherent dairy activity and routines, such as cattle milking and feeding at least twice a day, all along 

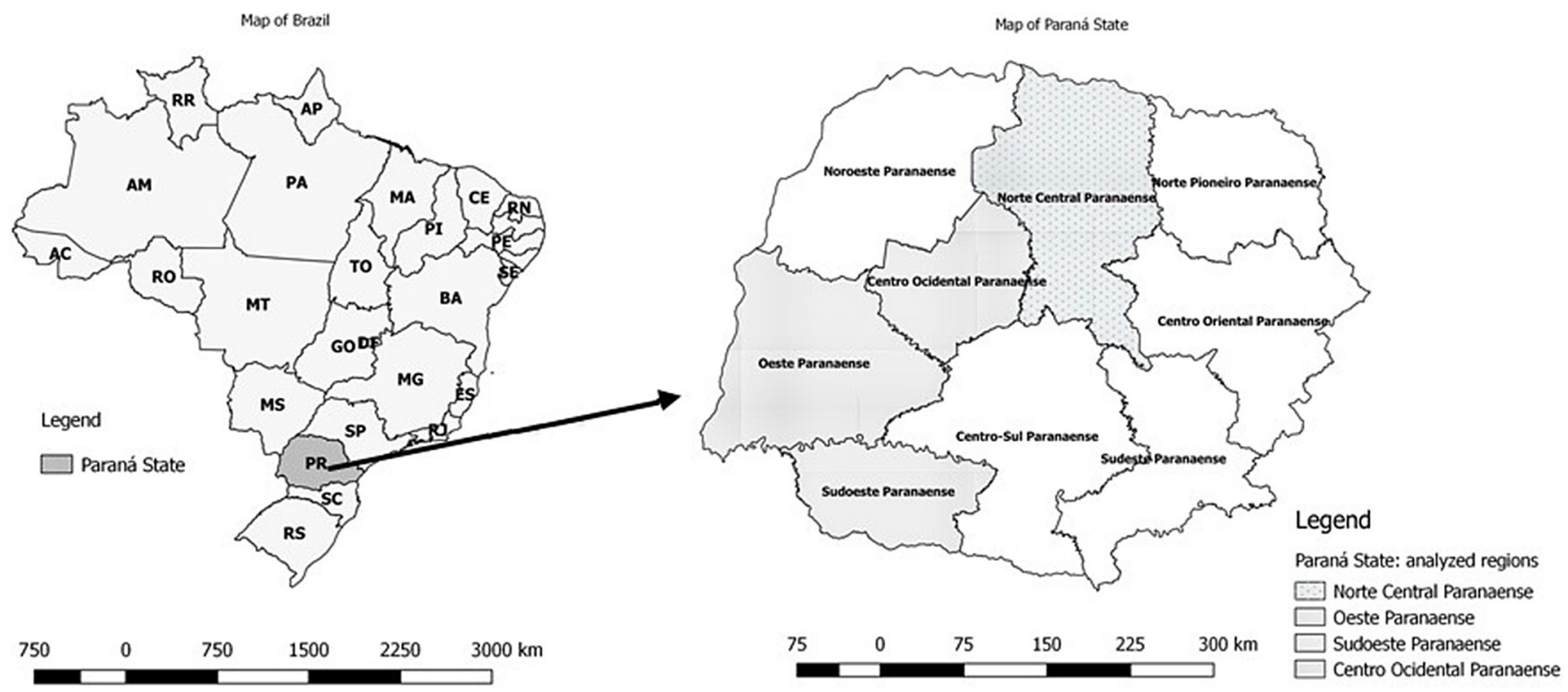

Fig. 1. Paraná State and analyzed regions.

Fig. 1. État du Paraná et régions d'étude.

the year (Dos Santos et al., 2012). Those activities tend to be even harder in family-based systems, since benefits from labor regulation (such as paid vacation, eight-hour work journey and six-day work week) are generally ignored among family members. Besides that, dairy workers tend to perform their routine activities under poor ergonomic conditions, involving repetitive tasks and big physical effort (Milano, 2013). Moreover, dairy family-based farms in Paraná present lower technology level (IPARDES, 2009), having less access to machinery and equipment and turning dairy farm routine even more labor-intensive. In such situations, labor conditions may be critical for potential family successors to remain on dairy activity. Finally, poor quality of life in rural area and lower income are some of the drawbacks influencing decision toward rural exodus, affecting family succession (Carneiro, 2001; Ferrari et al., 2004; Matte et al., 2015b).

Considering the influence of structural features in family's decision making, the apparent poorer labor conditions in family-based systems and the importance of family succession in dairy activity in Paraná, this paper aims to discuss labor conditions, family succession and structural features in Paranás dairy activity, considering family-based and hiredwork dairy production systems (DPS). Our hypothesis is that family-based DPS present poorer structure, poorer labor conditions and are less prone to family succession, compared to hired-labor DPS. This paper is organized as follows: after this introduction, the next section comprises the methodological procedures. Then, the third section includes results and discussions. Finally, we present conclusions and final remarks.

\section{Method}

In order to answer objectives and hypothesis, this research followed a quantitative approach, through the development of the following stages:

\subsection{Farm sampling and selection}

The method comprised interviews with 153 dairy farmers in Paraná State, Brazil, conducted in 2014 and 2015. Farmers were randomly selected considering previous contact lists provided by dairy cooperatives and Emater, the official technical assistance institution in Paraná (Yabe et al., 2015; Zimpel et al., 2017). According to Emater's representatives, those lists comprised the great majority of dairy farmers in four selected regions: Central North, West, Southwest and Midwest (Fig. 1). Locations were selected due to their representativeness in dairy production, also considering their heterogeneity (Brito et al., 2015). The four regions together comprised $47 \%$ of dairy farmers and $50 \%$ of family-based dairy farms in Paraná State (IBGE, 2006).

\subsection{Farmers' interviews}

The method comprised in situ face-to-face interviews (Schlecht and Achim, 2012). The questionnaire included questions concerning DPS characteristics, farmers and workers' social and economic profile, labor conditions and intent to family succession in dairy activity. We first performed descriptive analysis on farmers' and farms profile. Variables related to DPS, farmers and worker's characteristics (V1-V10) were metrics, applied for descriptive analysis (Tab. 1). Face-toface interviews also enabled the gathering of qualitative data, enriching results and discussion.

\subsection{The grid of variables}

From the interviews, we could compose a grid of variables to be analyzed. Variables concerning DPS characteristics and social and economic profile have been widely applied in other studies with similar purposes (Castel et al., 2010; Gabbi et al., 
Table 1. Variable characteristics.

Tableau 1. Description des variables.

\begin{tabular}{|c|c|c|}
\hline Variables & Answer type & Applied in \\
\hline V2. Milk production (liters per day) & Metric & $\mathrm{D} / \mathrm{CFA}$ \\
\hline V4. Number of cows in milk (heads) & Metric & $\mathrm{D} / \mathrm{CFA}$ \\
\hline V5. Milk productivity (liters/cow/day) & Metric & $\mathrm{D}$ \\
\hline V6. Milk productivity (liters/area) & Metric & $\mathrm{D}$ \\
\hline V8. Farmer's age (years) & Metric & $\mathrm{D}$ \\
\hline V9. Work hours per day (hours/day) & Metric & $\mathrm{D}$ \\
\hline V10. Absent work days (days/year) & Metric & $\mathrm{D}$ \\
\hline V11. Incentives to labor training & Likert Scale (0 to 10$)$ & CFA \\
\hline V12. Satisfaction with dairy activity & Likert Scale (0 to 10$)$ & CFA \\
\hline V13. One day off/week & Likert Scale ( 0 to 10$)$ & CFA \\
\hline
\end{tabular}

D: descriptive analysis; G: group definition; CFA: common factor analysis.

2013; IPARDES, 2009; Kaouche-Adjlane et al., 2015; Zimpel et al., 2017). In this research, DPS characteristics included production capacity (V1), production scale (V2, V3 and V4) and productivity (V5 and V6). As a rule, non-family-based DPS present higher production capacity, larger scale and higher productivity (IPARDES, 2009; de Souza and Buainain, 2013). Variables for social and economic profile comprised the experience in dairy activity (V7) and farmer's age (V8), also related to path dependency.

Labor conditions can include aspects such as wage, benefits and workload (ILO, 2014), and are widely applied in the analysis of working conditions, especially in small-scale family farming studies (Costa, 2011; Janker and Mann, 2018; Crockett, 2004). The choice of variables comprising labor conditions took into consideration the most important Brazilian legal requirements under the Consolidated Labor Laws (Brasil, 1943), also supported on researches about labor conditions in dairy activity (Dos Santos et al., 2012; Mugera and Bitsch, 2005). Thus, variables V9, V10, V13 and V14 represent the minimum legal labor standards according to Brazilian law. Variable V11 corresponds to incentives for labor training, as a benefit connected to labor condition. In general, due to higher enforcement on hired labor relations, non-familybased DPS may present better labor conditions (specially in terms of workload and benefits), when compared to familybased DPS.

Finally, variables V12, V15 and V16 correspond to incentives to remain in dairy activity and family succession. The level of satisfaction with dairy activity (V12), the economic difficulties (V15) and the intent for family succession (V16) are important aspects to determine family succession (Costa and Ralisch, 2013; Facioni et al., 2015; Savian, 2014; Suess-Reyes and Fuetsch, 2016) (Tab. 1).
Table 2. Group definition.

Tableau 2. Définition des groupes.

\begin{tabular}{lrc}
\hline Type of work force & $\mathrm{N}$ & Percentage \\
\hline Exclusively family workers DPS (Group 1) & 117 & 76.5 \\
Hired workers DPS (Group 2) & 36 & 23.5 \\
Total & 153 & 100 \\
\hline
\end{tabular}

\subsection{Statistical analysis}

For statistical analysis, we first separated the 153 DPS into two groups. For groups definition, we applied a dummy variable (V17) (Tab. 1). Thus, Group 1 (G1) comprised 117 DPS involving exclusively family workers (V17=1), and Group 2 (G2) comprised 36 farms using hired-labor for dairy activity $(\mathrm{V} 17=0)$. G1 represents family-based DPS and G2 corresponds to non-family-based DPS (Tab. 2).

Variables related to farmer's decision and intent to family succession (V11 to V16) were Likert (Likert, 1932), with a score from 0 to 10 (Tab. 1) (De Lima et al., 2013; Schlecht and Achim, 2012). Within the score, we considered zero (0) as the most pessimist farmer's perception about each issue; five (5) as an intermediate situation - not good/not bad, and ten (10) the best situation for farmer's perception about the issues.

After groups definition and descriptive analysis, we performed Common Factor Analysis (CFA) for 16 variables (V1 to V16) related to DPS characteristics, farmers' and workers' social and economic profiles, labor conditions and family succession (Tab. 1). Data were statistically treated and analyzed through the use of Statistical Package for Social Sciences - SPSS ${ }^{\circledR}$, version 18 (IBM, 2009). 
Table 3. Factor variance.

Tableau 3. Variance des facteurs.

\begin{tabular}{llll}
\hline Factors & \multicolumn{3}{c}{ Eigenvalues } \\
\cline { 2 - 4 } & Total & \% of Variance & Cumulative \% \\
\hline 1 & 3.526 & 39.179 & 39.179 \\
2 & 1.487 & 16.525 & 55.704 \\
3 & 1.282 & 14.249 & 69.953 \\
4 & 0.842 & 9.352 & 79.305 \\
5 & 0.782 & 8.69 & 87.996 \\
6 & 0.512 & 5.686 & 93.681 \\
7 & 0.264 & 2.939 & 96.62 \\
8 & 0.175 & 1.943 & 98.563 \\
9 & 0.129 & 1.437 & 100 \\
\hline
\end{tabular}

Extraction Method: Principal Component Analysis.

For the common factor analysis, we used principal component as the extraction method; varimax rotation type; standardization of Kaiser Meyer Olkin (KMO) and Bartlett's test of sphericity (Hair et al., 2009; Lebart, 2000).

Common Factor Analysis is a technique used to merge a set of interrelated variables into one or more factors. Each factor is defined by variables presenting a large correlation among each other and little correlation with the variables forming other factors (Fávero et al., 2009; Hair et al., 2009). Each factor represents a set of variables. Thus, CFA was used in order to treat more objectively a large set of variables. Factors are estimated through the combination of linear variables, as in equation (1):

$$
\begin{aligned}
& F_{1}=d_{11} * X_{1}+d_{12} * X_{2}+\cdots+d_{1 m} * X_{i}, \\
& F_{2}=d_{21} * X_{1}+d_{22} * X_{2}+\cdots+d_{2 m} * X_{i}, \\
& \vdots \\
& F_{m}=d_{m 1} * X_{1}+d_{m 2} * X_{2}+\cdots+d_{m i} * X_{i} .
\end{aligned}
$$

Where:

- $F_{m}=$ common factors;

- $d_{m i}=$ coefficient of factorial scores;

- $X_{i}=$ original variables.

Considering the standardization of variables (mean 0 and standard deviation 1), Factorial Analysis model can be generically presented as in equation (2):

$$
X_{i}=a_{i 1} F_{1}+a_{i 2} F_{2}+\cdots+a_{i m} F_{m}+{ }_{i} \quad(i=1, \cdots, p)
$$

Variables presenting low or medium factor loadings (lower than $|0.05|$ through Pearson method) were removed. To define the number of factors, we considered Eigenvalues greater than $|1.0|$, and a minimum accumulated variance of $60 \%$ (Fávero et al., 2009; Hair et al., 2009).

From initial 16 variables, we performed Common Factor Analysis (CFA), forming nine factors (Tab.3). The first results demonstrated that the three first factors must remain, once they presented Eigenvalue higher than 1.0 and accumulate $69.9 \%$ of total explained variance (Fávero et al., 2009; Hair et al., 2009) (Tab. 3).

The cumulative variance of the three factors (69.9\%) satisfied the minimum criteria. Furthermore, analysis resulted in KMO value of 0.742 and Bartlett's test of 0.00 , indicating that the variables used are suitable for exploratory factor analysis statistics (Fávero et al., 2009; Hair et al., 2009).The variables that composed each Factor and their respective descriptions are presented in Table 4. The nine final variables defined three factors, named "structure" (F1), "labor conditions" (F2) and "individual conditions to family succession" (F3). High factor loads indicate how variables will be grouped in each factor (Tab. 4). Thus, our analysis considered three of the nine initial factors (Tab. 4), composed of nine variables, as follows:

- milk production (liters per day) (F1);

- number of cows (heads) (F1);

- number of cows in milk (heads) (F1);

- incentives to labor training: this variable is related to the support for training courses on labor and dairy practices for workers on a regular basis (F2);

- satisfaction with dairy activity: this variable is related to the general level of farmer's satisfaction with dairy activity (F3);

- family succession: this variable is related to the intent of a farmer's child to succeed his parent on dairy activity at the farm (F3);

- one day off per week (F2): this variable is related to the benefit of a six-day work week to workers (family and/or hired labor);

- vacation (F2): this variable is related to the benefit of vacation for workers (family and/or hired labor);

- economic difficulties: this variable is related to the farmer's perception on economic difficulties in dairy activity (F3).

After generating the factors, we performed mean tests between G1 and G2. To compare groups, we performed Student's t-test. Doing so, we could compare family-based and non-family-based dairy farms in terms of structure, labor conditions and family succession.

\section{Results}

The separation of DPS in two groups according to the type of labor in dairy activity - exclusively family workers (G1) and hired workers (G2) - showed that G1 is more represented $(76.5 \%)$ in the sample analyzed (Tab.2). This finding is in consonance with the profile of DPS in Paraná: according to Ipardes (2009), 85\% of DPS in the State use only family labor to conduct dairy production.

Table 5 presents descriptive statistics. The average area managed by 153 farmers was 48 hectares, containing an average of 42 dairy cows. For these 42 dairy cows, farmers declared, on average, 22 cows in milk. Average milk production was 325 liters per day, comprising a productivity of 13.6 liters of milk/cow/day, on average. Regarding farmers, the average age was 47 years old, with an average of 17.6 years of experience in dairy production. The average of hours in work was 6.3 hours a day. The number of work absences caused by injuries was, on average, 2.5 days/year (Tab. 5).

From Table 5, family-based farms are smaller in area, number of animals and production, although presenting similar 
performance in terms of productivity. They seem to be younger, although more experienced, when compared to farmers hiring labor. As for labor aspects, they seem to have more flexibility in terms of daily working hours, which can be explained by their large autonomy when compared to hiring workers situations. Finally, for both groups, annual workers'

Table 4. Factor matrix.

Tableau 4. Matrice des facteurs.

\begin{tabular}{lrrr}
\hline \multicolumn{1}{c}{ Variables } & \multicolumn{2}{l}{ Factors } & \\
\cline { 2 - 4 } & F1 & \multicolumn{1}{c}{ F2 } & \multicolumn{1}{c}{ F3 } \\
\hline 1. Incentives to labor training & -0.068 & 0.810 & 0.187 \\
2. Satisfaction with dairy activity & 0.084 & 0.244 & 0.627 \\
3. Family succession & -0.010 & -0.136 & 0.733 \\
4. One day off per week & 0.393 & 0.764 & 0.080 \\
5. Vacation & 0.379 & 0.744 & -0.170 \\
6. Economic problems & 0.058 & 0.049 & 0.687 \\
7. Milk production (liters/day) & 0.873 & 0.246 & 0.181 \\
8. Number of cows (heads) & 0.939 & 0.080 & -0.032 \\
9. Number of cows in milk (heads) & 0.925 & 0.172 & 0.058 \\
\end{tabular}

Extraction Method: Principal Component Analysis.

Rotation Method: Varimax with Kaiser Normalization. absent days are very low, and especially lower for familybased farmers, once their absence may bring harmful effects to their own business.

Concerning factorial analysis, some initial remarks are relevant. Factor 1 ("structure") explained most of the variance between the two groups (39.2\%) (Tab.3). It means that variables in Factor 1 are those mostly differing Groups 1 and 2. Factor 1 comprised number of cows, volume of milk, and number of cows in milk (Tab. 4). Those variables indicate dairy structural features. Thus, family-based and non-family-based dairy farms diverge mainly in terms of structure, the former being smaller. Factor 2 ("labor conditions") explained 16.5\% of total variance between G1 and G2 (Tab.3), formed by variables related to labor: incentives to training courses, workers' weekly day off and workers' vacation (Tab.4). Finally, Factor 3 ("individual conditions to family succession") corresponded to $14.2 \%$ of total variance between the two groups (Tab. 3). Variables in Factor 3 are: the degree of satisfaction with dairy activity, the intent upon family succession, and economic difficulties in dairy activity (Tab. 4). Those three factors together greatly explain the differences between family and non-family-based dairy farms in Paraná State.

Common Factor Analysis allowed a comparative analysis between the two groups (Tabs. 5 and 6). Results indicate that DPS in the two groups are different for the three aspects (structure, labor conditions and individual conditions for

Table 5. Descriptive statistics.

Tableau 5. Statistiques descriptives.

\begin{tabular}{lcccrr}
\hline & $\mathrm{N}$ & Minimum & Maximum & Average & Standard Deviation \\
\hline Total area (hectares) & 153 & 0.6 & 1331 & 47.9 & 162.9 \\
Milk production (liters per day) & 153 & 20 & 2000 & 324.6 & 317.8 \\
Number of cows (heads) & 153 & 5 & 180 & 42.6 & 30.1 \\
Number of cows in milk (heads) & 153 & 3 & 32 & 22.2 & 14.4 \\
Milk productivity (liters/cow/day) & 153 & 2 & 134 & 28.9 & 6.3 \\
Milk productivity (liters/area) & 153 & 0.86 & 60 & 17.6 & 27.1 \\
Experience in dairy activity (years) & 153 & 1 & 86 & 47.9 & 12.2 \\
Farmer's age (years) & 152 & 22 & 13 & 6.3 & 12.2 \\
Work hours per day (hours/day) & 153 & 2 & 90 & 2.5 & 10.8 \\
Absent work days (days/year) & 153 & 0 & &
\end{tabular}

Table 6. Factorial score means for G1 and G2.

Tableau 6. Moyennes des scores factoriels pour G1 et G2.

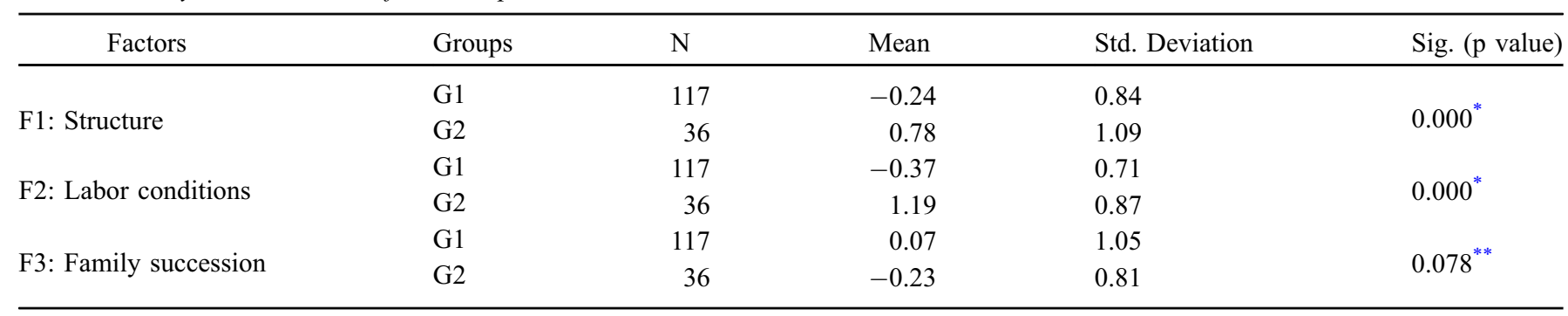

\footnotetext{
${ }^{*}$ Sig $1 \%$;

${ }^{* *}$ Sig $10 \%$.
} 


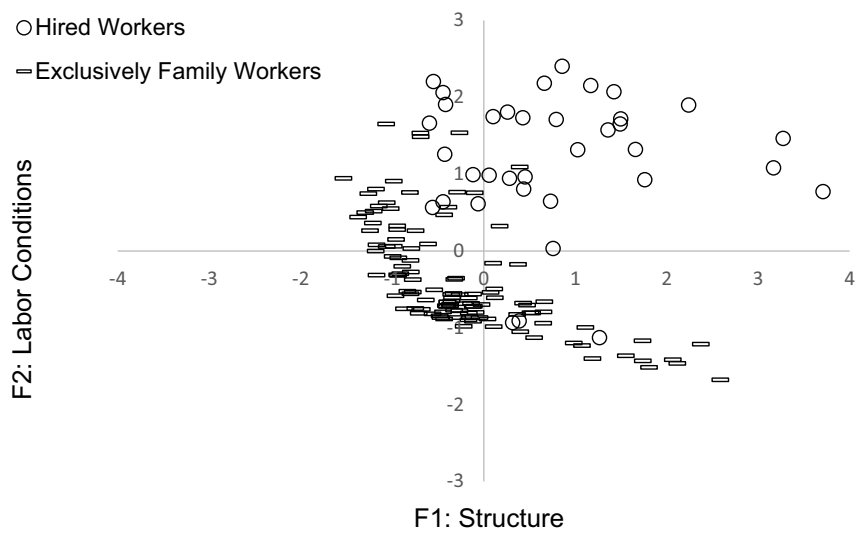

Fig. 2. Groups of dairy production systems for Factor 1 (structure) and Factor 2 (labor conditions).

Fig. 2. Groupes de systèmes de production laitière pour Facteur 1 (structure) et Facteur 2 (conditions de travail).

family succession). DPS in G1 presented low-scale structural characteristics, when compared to those in G2, which supports previous descriptive analysis (Tab. 5). In general, family-based dairy farms are smaller in area, herd and production scale (IPARDES, 2009; de Souza and Buainain, 2013).

Concerning F2, DPS in G2 provide better labor conditions when compared to G1 (Tabs. 5 and 6). Since variables are mostly related to legal requirements, it is expected that dairy farms using hired labor may be more concerned on following legal labor standards. Poorer labor conditions in family-based DPS (G1) may be related to the low enforcement of legal labor standards among family workers. Besides that, it may be influenced by the potential lower technological level and its consequent harder work.

Variables forming F3 are explicitly related to individual conditions to family succession (Tab. 4). The connection of those three variables in one factor is supported on other studies (Gris et al., 2017). Data showed that family-based dairy farmers present higher individual conditions for family succession (Tabs. 5 and 6). Although showing inferior structure and worse labor conditions, they are more prone to family succession. The intent toward family succession may result from family-based DPS internal features, generally consisting of small productive structure and production scale (IPARDES, 2009; de Souza and Buainain, 2013). Besides that, the apparent favorable opportunity costs of dairy activities, when compared to urban low-quality work (Novo et al., 2012), associated to famer's low level of education and low technical skills for different activities (Zimpel et al., 2017) may incentivize family succession in family-based DPS.

Illustrations and simultaneous analysis of factors (Figs. 2 and 3) support some important remarks. Small-scale farmers are in Group 1, and larger DPS are those using hired labor (Group 2) (Fig. 2). This is expected, since high levels of productive resources and production requires a large number of people engaged in activities, and the consequent need to complement family labor with non-family employees. Moreover, DPS using hired labor (Group 2) seem to be more concerned with labor conditions. It reinforces that the use of hired workers and the consequent need to meet legal requirements may drive farmers to pay more attention to

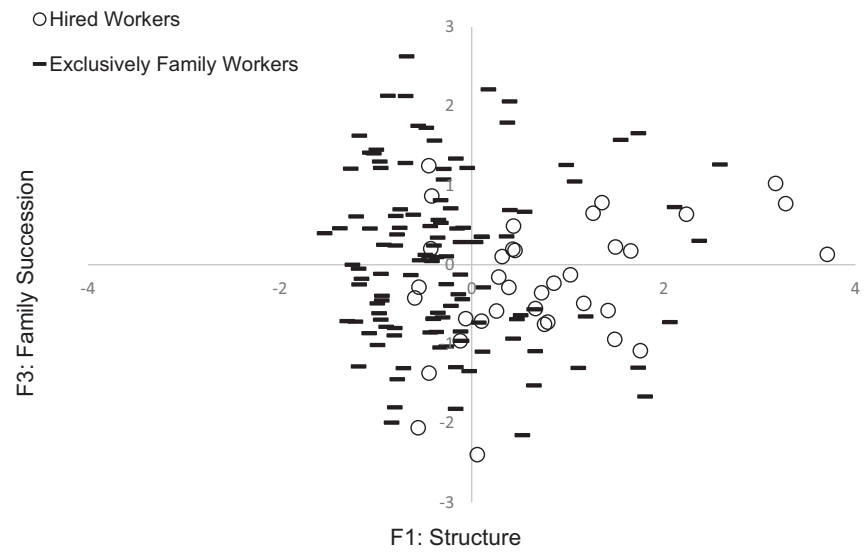

Fig. 3. Groups of dairy production systems for Factor 1 (structure) and Factor 3 (family succession).

Fig. 3. Groupes de systèmes de production laitière pour Facteur 1 (structure) et Facteur 3 (succession familiale).

such aspects. Dairy farmers give hired workers benefits such as vacation periods and weekly day-off, but do not necessarily provide those rights to themselves or to their own family members.

Farmers in both groups seem to be dissatisfied with the dairy activity and not so interested in family succession, given the large number of observations in the lower quadrants for Factor 3 (Fig. 3). Concerning the simultaneous analysis of data in Factors 1 and 3, it indicates that farmers in less favorable structural conditions (small-scale) are less dissatisfied with dairy activity and more prone to family succession, despite its economic problems. Dispersion of DPS in Figures 2 and 3 reinforces the previously mentioned heterogeneity of DPS for all the three factors, in both groups.

\section{Discussion}

Concerning descriptive analysis, despite the differences between groups, in general, data indicated that a relatively small-scale production was conducted by experienced and not so young farmers. Nevertheless, high standard deviations suggest heterogeneity among DPS in both groups, lending support to Ipardes (2009), Brito et al. (2015) and Zimpel et al. (2017), among others. In general, descriptive data are in accordance with the findings of other studies. Yabe et al. (2015) analyzed 100 DPS in the northern and northwestern portion of Paraná State. They presented, on average, about 30 hectares and 16 cows in milk, producing 143 liters per day. It indicates lower productivity in that region, when compared to the present research. Lange et al. (2016) analyzed 735 DPS in the western portion of Paraná, showing an average of 15 cows in milk and 242 liters per day, which indicates a level of productivity similar to this research. Zimpel et al. (2017) studied 55 DPS in the western part of the State, with an average area of 33 hectares and 37 cows in milk, indicating a higher level of productivity. Thus, it shows the large heterogeneity in DPS in Paraná, which makes decision-making complex.

Factor analysis allows some important discussion. High structural levels (Factor 1) may allow for higher efficiency due to economies of scale and higher bargaining power with buyers 
(Brito et al., 2015). In Brazil, volume of milk is an important variable for the set of price per liter to be paid for dairy farmers. Farmers producing more tend to receive a higher price (per liter), due to economies of scale (Jank and Galan, 1998; Oaigen et al., 2013; Parré et al., 2011). Besides that, high production levels tend to dilute fixed costs and reduce unitary production costs, improving economic efficiency of dairy production system (Simões et al., 2009). In general, researches state that high-scale DPS tend to generate higher income, thus being more prone to family succession (Kimhi and Bollman, 1999; Matte and Machado, 2016; Suess-Reyes and Fuetsch, 2016).

Structural features can be determinant for decision making in family farming (Ferguson and Hansson, 2013; von Thünen, 1966). Low-income levels in family-based DPS may indicate restricted access to capital to invest in equipment and technology to support routine activities and improve labor conditions (de Souza and Buainain, 2013), thus decreasing the probability of family succession (Suess-Reyes and Fuetsch, 2016). Larger farms show a higher probability of family succession (Glauben et al., 2004; Glauben et al., 2009; Mishra and El-Osta 2007; Valeeva et al., 2007). In dairy activity particularly, larger and more profitable dairy farms are more prone to family succession (Glauben et al., 2009).

In Brazil, production scale is a main determinant of financial profitability, being important for total production cost reduction and income increase, due to better prices for higher volumes (Sabbag and Costa, 2015). Volume is a driven factor for milk price in transactions between dairy farmers and buyers (Araújo and Silva, 2014). Results on F1 indicate poorer production structure in G1, which may hinder the possibilities of income increase and create disincentives for family succession (Suess-Reyes and Fuetsch, 2016).

Features concerning human resources, workers and managers, related to Factor 2, affect family succession and farmer's decision on remaining in activity (Hitt and Tyler, 1991; Novo et al., 2012; Suess-Reyes and Fuetsch, 2016). The lack of training and of labor benefits are remarkable problems in dairy farming, creating dissatisfaction and health problems (Dos Santos et al., 2012), and thus turning farmers less prone to family succession. In fact, rural labor has been considered less attractive due to its arduousness, depreciation and low remuneration (Carneiro, 2001; Matte and Machado, 2016; de Mello et al., 2003; Novo et al., 2012; Spanevello et al., 2012).

Individual conditions to family succession formed the less important factor for the variance between the two groups (Tab. 3). Nevertheless, statistical difference between groups indicates that satisfaction in dairy activity, economic aspects and intent upon family succession are different between family-based and non-family-based dairy farmers, the former being more prone to family succession (Tab. 6).

According to Suess-Reyes and Fuetsch (2016), family succession strategy in farming systems is multifaceted, connected to different aspects, such as farm-related resources (e.g. structure, management and performance), family-related resources (e.g. emotional ties, conflicts and knowledge transfer), and operator- and successor-related resources (e.g. education level, age and number of family members). Following that rational, Factor 3 represents the combination of economic issues and more subjective aspects, corroborating the multidimensionality of family succession.
Although the probability of family succession tends to be higher in large-scale and more efficient production systems, social and cognitive-related characteristics, values and personal motivation, as well as labor force characteristics, seem to be major factors for farmers' decision making (Gris et al., 2017; Hitt and Tyler, 1991; Matte and Machado, 2016; Suess-Reyes and Fuetsch, 2016).

At first sight, results concerning the comparison between G1 and G2 seem to be paradoxical: dairy farmers with poorer structure and worse labor conditions show higher individual conditions for family succession. However, when considering that family succession is multidimensional, including economic, social, relational and behavioral aspects (Gris et al., 2017; Kerbler, 2012; Suess-Reyes and Fuetsch, 2016), we can infer that other factors than structure and labor conditions are affecting individual conditions for family succession in this study.

Family farm succession is a complex decision, probably involving different aspects. Indeed, variables related to family succession can be quite complex. For example, the steady supply of family labor, typical of dairying (Mishra and El-Osta, 2007), may favor family ties and identity to dairy activity, thus influencing individual conditions to family succession; farming experience may influence family succession (Cavicchioli et al., 2015), which may help us to understand why farmers in Group 1 are more prone to family succession. Even in the economic perspective, the issue may be twofold: many dairy farmers, for example, consider the monthly income as a relevant element for family succession (Mishra and El-Osta, 2007), even if the profitability is not so interesting.

Family dairy workers consider that specific knowledge built during and for dairy activity are not substitutable, involve tacit knowledge and create human specificity. For familybased dairy farmers, DPS specific knowledge is high enough to bring prohibited sunk costs. Besides that, leaving dairy activity may bring high family reallocation costs (Mugera and Bitsch, 2005). On the one hand, specific knowledge may have a positive side, once family-based dairy farmers may face benefits and better performance, from learning by doing, for example. On the other hand, such specific knowledge may create a lock-in situation, reinforcing a path dependence and the continuity of a potential bad cycle for family-based dairy farmers in Paraná. Finally, other subjective aspects may be high enough to keep G1 farmers in dairy activity (Morais et al., 2017), such as the emotional bonds to the land (Grubbström and Sooväli-Sepping, 2012).

Structural aspects, labor conditions and individual conditions to family succession may affect dairy farmers' decision making, as supported in many studies (Brouthers et al., 2000; Hansson and Ferguson, 2011; Hitt and Tyler, 1991; Magalhães 2009; Novo et al., 2012). Nevertheless, our hypothesis was only partially supported: family-based dairy farmers present poorer structural features and worse labor conditions but are more prone to family succession.

\section{Conclusion}

The present study brings a set of notable results to Paraná's dairy sector and this scientific field of research, opening room for conclusions and final remarks. First, DPS employing 
exclusively family labor differ from those employing hired labor, namely in terms of structure, labor conditions and individual conditions to family succession. Structural features are of great importance in that case, indicating that larger dairy farmers are those hiring labor in Paraná.

Most of DPS in Paraná State do not hire labor (Group 1), depending exclusively on family work to conduct dairy activity. Dairy production systems in Paraná are heterogeneous in different aspects, even when considering DPS in the same group. Such heterogeneity makes the design and implementation of public policies complex.

Dairy farmers not hiring labor present poorer structural and labor conditions, although being more prone to family succession, partially supporting this research hypothesis. It seems that those dairy farmers have other incentives to remain in the dairy activity, which motivates family succession. This may come from different factors, such as the high financial dependence on dairy activity, as well as to cognitive-related characteristics, values and personal beliefs. It suggests a greater relevance of individual, behavioral, emotional and social aspects of dairy activity for family-based farmers, when compared to farmers using hired work. Despite their interest in continuing dairy activity, results indicate the need to improve labor conditions, especially in DPS in G1, since most family workers are not given the right to a weekly day-off or vacation, and do not support training courses on a regular basis.

The study also revealed an important drawback: such DPS present worse labor conditions, which may bring immediate and future sound consequences. Working conditions is an important aspect of farming sustainability (Van Calker et al., 2005). Although family farmers are more prone to promote family succession, poor labor conditions may threaten family succession in the very long run. Thus, efforts to improve family work conditions are necessary to ensure long-term sustainability of dairy farming in Paraná State. Once dairy is a laborintensive activity, demanding working on a daily basis, other mechanisms should be considered to support routine DPS activities, such as labor schedule and labor planning with other farmers.

There seems to be other motivations concerning labor conditions and family succession. On the one side, farmers might be resigned to labor conditions in the dairy activity, taking it for granted. On the other side, their involvement in dairy activity and consequent path dependence might create a favorable attitude towards the continuity of the dairy activity. Structural features and labor conditions seem not to be the driving factors for the intent to family succession in DPS.

All these issues deserve deeper investigation, as well as other aspects. Future research considering other perspectives and potential factors would be helpful to understand dairy farmers' family succession in Paraná State. Family succession needs to be treated in a multidisciplinary perspective, interconnected to other aspects. Further studies could bring advances through the investigation of some specific social, market, technology and political features directing decisionmaking in family farming. In the same sense, expanding the variables for labor conditions and structure, as well as including other social and behavioral factors could put more light on the differences between dairy farms using and not using hired labor. It reinforces the need for interdisciplinary studies, already mentioned in other studies. Finally, a deep investigation on labor conditions and the reasons why familybased dairy farmers do not promote better labor conditions is critical for Paraná's dairy sector.

Acknowledgment. This research was funded by Fundação Araucária - Convênio 265/14-UEM/FUNDAÇÃ̃O ARAUCÁRIA.

\section{References}

Araújo LV, Silva SP. 2014. Agricultura familiar, dinâmica produtiva e estruturas de mercado na cadeia produtiva do leite: Elementos para o desenvolvimento territorial no Noroeste de Minas. Rev Bras Gest e Desenvolv Reg 10: 52-79.

Brasil. 1943. Consolidação das leis do trabalho. Brasil: Governo Federal.

Brito MM, Bánkuti FI, Bánkuti SMS, Santos GT, Damasceno JC, Massuda EM. 2015. Horizontal arrangements and competitiveness of small-scale dairy farmers in Paraná, Brazil. Int Food Agribus Manag Rev 18: 18.

Brouthers KD, Brouthers EL, Wener S. 2000. Influences on strategic decision-making in the dutch financial services industry. J Manage 26: 863-883.

Carneiro MJ. 2001. Herança e gênero entre agricultores familiares. Estud Fem 1: 22-55.

Castel J, Madry W, Gozdowski D, Roszkowska-Madra B, Dabrowski M, Lupa W, et al. 2010. Family dairy farms in the Podlasie province, Poland: farm typology according to farming system. Spanish J Agric Res 8: 946-961.

Cavalheiro CN, Rempel C. 2014. Perfil socioeconômico e análise da qualidade de vida dos produtores de leite da comunidade São Justino, em Juína/MT. Rev Destaques Acadêmicos 6: 148-156.

Cavicchioli D, Bertoni D, Tesser F, Frisio DG. 2015. What factors encourage intrafamily farm succession in mountain areas? Mt Res Dev 35: $152-160$.

Costa FLM, Ralisch R. 2013. A juventude rural do assentamento Florestan Fernandes no município de Florestópolis (PR). Rev Econ e Sociol Rural 51: 415-432.

Costa MRC. 2011. O futuro entre o rural e o urbano. Um estudo de caso sobre a juventude rural no município de Morro Redondo RS. Faculdade de Agronomia Eliseu Maciel da Universidade Federal de Pelotas.

Crockett J. 2004. The nature of farm succession in three New South Wales communities. AFBM J 2004-1: 14-27.

De Lima IF, De Oliveira HPC, De Santana SR. 2013. Metodologia para avaliação do nível de usabilidade de bibliotecas digitais: Um estudo na Biblioteca Virtual de Saúde. Transinformacao 25: 135143.

de Mello MA, Abramovay R, Silvestro ML, Dorigon C, Ferrari DL, Testa VM. 2003. Sucessão hereditária e reprodução social da agricultura familiar. Agric São Paulo 50: 11-24.

de Souza RP, Buainain AM. 2013. A competitividade da produção de leite da agricultura familiar: os limites da exclusão. Estud Soc e Agric 21: 308-331.

Debres LM. 2014. Projeto de Juventude rural, campo de possibilidades e migração: um estudo documental do Centro de Desenvolvimento do Jovem Rural (CEDEJOR). Rev Monogr Ambient 13: 3963-3976.

DIEESE. 2011. Estatísticas do meio Rural 2010-2011. Estatísticas do meio Rural: 291.

Dos Santos JCF, Hostiou N, Damasceno JC, Dedieu B. 2012. Room for manoeuvre in time of the workforce in dairy production systems. Rev Bras Zootec 41: 2450-2457. 
Facioni D, Wemerson M, Pereira G. 2015. Análise dos determinantes. Analysis of determining factors of the succession in rural. Organ Rurais Agroindustriais 17: 119-136.

Fávero LP, Belfiore PP, Silva FL da, Chan BL. 2009. Análise de dados: Modelagem multivariada para tomada de decisões. In: Análise de dados: modelagem multivariada para tomada de decisões. 3rd Edition. Rio de Janeiro: Elsevier, 544 p.

Ferguson R, Hansson H. 2013. Expand or exit? Strategic decisions in milk production. Livest Sci 155: 415-423.

Ferrari DL, Abramovay R, Silvestro ML, Mello MA De. 2004. Dilemas e estratégias dos jovens rurais: ficar ou partir? Estud Soc e Agric 12: 237-271.

Foguesatto CR, Artuzo FD, Lago A, Machado JAD. 2016. Fatores Relevantes para a Tomada de Decisão dos Jovens no Processo de Sucessão Geracional na Agricultura Familiar. Rev Parana Desenvolvimento-RPD 37: 15-28.

Gabbi AM, McManus CM, Silva AV, Marques LT, Zanela MB, Stumpf MP, et al. 2013. Typology and physical-chemical characterization of bovine milk produced with different productions strategies. Agric Syst 121: 130-134.

Glauben T, Tietje H, Weiss CR. 2004. Intergenerational succession in farm households: evidence from Upper Austria. Rev Econ Househ 2: $443-462$.

Glauben T, Petrick M, Tietje H, Weiss C. 2009. Probability and timing of succession or closure in family firms: A switching regression analysis of farm households in Germany. Appl Econ 41: 45-54.

Gomes AL, Ferreira Filho JB de S. 2007. Economias de escala na produção de leite: uma análise dos estados de Rondônia, Tocantins e Rio de Janeiro. Rev Econ e Sociol Rural 45: 591-619.

Gris VGC, Lago SMS, Brandalise LT. 2017. Sucessão na agricultura familiar: produção científica brasileira na área de administração pública e de empresas, ciências contábeis e turismo (2004-2016). Extensão Rural - DEAER - CCR - UFSM 24: 7-30.

Grubbström A, Sooväli-Sepping H. 2012. Estonian family farms in transition: A study of intangible assets and gender issues in generational succession. J Hist Geogr 38: 329-339.

Hair JFJ, Black WC, Babin BJ, Anderson RE. 2009. Multivariate Data Analysis. 7th Edition. Saddle River: Prentice Hall.

Hansson H, Ferguson R. 2011. Factors influencing the strategic decision to further develop dairy production - A study of farmers in central Sweden. Livest Sci 135: 110-123.

Hitt MA, Tyler BB. 1991. Strategic decision models: Integrating different perspectives. Strateg Manag J 12: 327-351.

IBGE. 2006. Censo Agropecuário 2006. Censo Agropecuário.

IBGE. 2015. Pesquisa da Pecuária Municipal.

IBM. 2009. Statistical Program for Social Sciences - SPSS.

ILO. 2014. Rules of the game. A brief introduction to labour standards. Revised edition. International Labour Organisation.

IPARDES. 2009. Caracterização socioeconômica da atividade leiteira no Parná.

Jank MS, Galan VB. 1998. Competitividade do sistema agroindustrial do leite. ESALQ-PENSA-USP: 39-61.

Janker J, Mann S. 2018. The social dimension of sustainability in agriculture. A review of sustainability assessment tools. Ettenhausen, Switzerland: Agroscope, $18 \mathrm{p}$.

Joosse S, Grubbström A. 2017. Continuity in farming - Not just family business. J Rural Stud 50: 198-208.

Kaouche-Adjlane S, Ghozlane F, Mati A. 2015. Typology of dairy farming systems in the Mediterranean basin (Case of Algeria). Biotechnol Anim Husb 31: 385-396.

Kerbler B. 2012. Factors affecting farm succession: The case of Slovenia. Agric Econ (Czech Republic) 58: 285-298.
Kimhi A, Bollman R. 1999. Family farm dynamics in Canada and Israel: The case of farm exits. Agric Econ 21: 69-79.

Lange MJ, Zambom MA, Ramos CEC de O, et al. 2016. Tipologia de sistemas de produção leiteiros baseado nas características produtivas e de manejo na Região Oeste do Paraná. Semin Ciências Agrárias 37: 473-481.

Lebart L. 2000. Data Analysis. Berlin: Springer.

Leonard B, Kinsella A, O’Donoghue C, Farrell M, Mahon M. 2017. Policy drivers of farm succession and inheritance. Land use policy 61: $147-159$.

Likert R. 1932. A technique for the measurement of attitudes. Arch Psychol 22: 1-55.

Magalhães RS. 2009. A 'masculinização' da produção de leite. Rev Econ e Sociol Rural 47.

Matte A, Spanevello RM, Andreatta T. 2015a. Perspectivas De Sucessão Em Propriedades De Pecuária Familiar No Município De Dom Pedrito - Rs. Holos 1: 144-159.

Matte A, Machado JAD, Neske MZ. 2015b. Tomada de decisão e a sucessão na agricultura familiar no sul do Brasil. Mundo Agrário 16: $15-28$.

Matte A, Machado JAD. 2016. Tomada de decisão e a sucessão na agricultura familiar no sul do Brasil Decision making and. Rev Estud Sociais 18: 130-151.

MDA. Ministério do Desenvolvimento Agrário. 2015. Agricultura familiar produz $70 \%$ dos alimentos consumidos por brasileiros. Portal Brasil. http://www.brasil.gov.br/economia-e-emprego/ 2015/07/agricultura-familiar-produz-70-dos-alimentos-consumi dos-por-brasileiro.

Milano D de F. 2014. Organização e análise ergonômica do trabalho de produtores rurais na atividade leiteira. Programa de PósGraduação em Desenvolvimento. Universidade Regional do Noroeste do Estado do Rio Grande do Sul, 116 p.

Mishra AK, El-Osta H. 2007. Factors affecting succession decisions in family farm business: evidence form a national survey. JASFMRA 1: 9.

Morais M, Binotto E, Borges JAR. 2017. Identifying beliefs underlying successors' intention to take over the farm. Land use policy 68: 48-58.

Mugera AW, Bitsch V. 2005. Managing labor on dairy farms: A resource-based perspective with evidence from case studies. Int Food Agribus Manag Rev 8: 79-98.

Neto BS, Basso D. 2005. A produção de leite como estratégia de desenvolvimento para o Rio Grande do Sul. Desenvolvimento em questão 3: 53-72.

Nicholson CF, Gómez MI, Gao OH. 2011. The costs of increased localization for a multiple-product food supply chain: Dairy in the United States. Food Policy 36: 300-310.

Novo A, Jansen K, Slingerland M. 2012. The sugarcane-biofuel expansion and dairy farmers' responses in Brazil. J Rural Stud 28: 640-649.

Oaigen RP, Barcellos JOJ, Canozzi MEA, et al. 2013. Competitividade inter-regional de sistemas de produção de bovinocultura de corte. Ciência Rural 43: 1489-1495.

Oliveira LFT, Silva SP. 2012. Mudanças institucionais e produção familiar na cadeia produtiva do leite no Oeste Catarinense. Rev Econ e Sociol Rural 50: 705-720.

Parré JL, Bánkuti SMS, Zanmaria AN. 2011. Perfil socioeconômico de produtores de leite da região Sudoeste do Paraná: um estudo a partir de diferentes níveis de produtividade. Rev Econ $e$ agronegócio 9: 275-300.

Pietola K, Vare M, Lansink O. 2003. Timing and type of exit from farming: farmers' early retirement programmes in Finland. Eur Rev Agric Econ 30: 99-116. 
Robinson TP, Wint GRW, Conchedda G, et al. 2014. Mapping the global distribution of livestock. PLoS One 9: e96084.

Royer A. 2011. Transaction costs in milk marketing: A comparison between Canada and Great Britain. Agric Econ 42: 171-182.

Sabbag OJ, Costa SMAL. 2015. Análise de custos da produção de leite: aplicação do método de Monte Carlo. Rev Extensão Rural DEAER - CCR - UFSM, St Maria 22: 125-145.

Savian M. 2014. Sucessão geracional: garantindo-se renda continuaremos a ter agricultura familiar? Rev Espaço Acadêmico 14: 97-106.

Schlecht S, Achim S. 2012. A latent class cluster analysis of farmers' attitudes towards contract design in the dairy industry. Agribusiness 28: $121-134$.

Simões ARP, Silva RM Da, Oliveira MVM De, Cristaldo RO, Brito MCB. 2009. Avaliação econômica de três diferentes sistemas de produção de leite na região do Alto Pantanal Sul-mato-grossense. Agrarian 2: 153-167.

Suess-Reyes J, Fuetsch E. 2016. The future of family farming: A literature review on innovative, sustainable and successionoriented strategies. J Rural Stud 47: 117-140.

Spanevello RM, De Azevedo LF, Vargas LP. 2012. A migração juvenil e implicações sucessórias na agricultura familiar. Rev Ciências Humanas 45: 291-304.

Telles TS, Tanaka JMU, Pellini T. 2008. Agricultura familiar: pecuária leiteira como locus das políticas públicas paranaenses. Semin Ciencias Agrárias 29: 579-590.
USDA. 2015. Market and Trade, custom query. Mark trade.

Van Calker KJ, Berentsen PBM, Giesen GWJ, Huirne RBM. 2005. Identifying and ranking attributes that determine sustainability in Dutch dairy farming. Agric Human Values 22: 53-63.

Van Der Ploeg JD. 2010. Rural development reconsidered: building on comparative perspectives from China, Brazil and the European Union. Riv Di Econ Agrar 65: 163-190.

Valeeva NI, Lam TJGM, Hogeveen H. 2007. Motivation of dairy farmers to improve mastitis management. J Dairy Sci 90: 4466-4477.

von Thünen JH. 1966. Isolated State. Prog Hum Geogr 20: 18.

Williamson OE. 1985. The Economic Institutions of Capitalism. New York: The Free Press.

Yabe MT, Bánkuti FI, Damasceno JC, de Brito MM. 2015. Characteristics of milk production systems and feed strategies for dairy cows in the North and Northwest of Paraná State. Semin Ciências Agrárias 36: 4469-4480.

Zimpel R, Bánkuti FI, Zambom MA, Kuwahara KC, Bánkuti SMS. 2017. Characteristics of the dairy farmers who perform financial management in Paraná State, Brazil. Rev Bras Zootec 46: $421-428$.

Zúñiga-Vicente JÁ, de la Fuente-Sabaté JM, Suárez-González I. 2005. Facilitating and inhibiting factors behind strategic change: Evidence in the Spanish private banking industry, 1983-1997. Scand J Manag 21: 235-265.

Cite this article as: Bánkuti FI, Damasceno JC, Schiavi SM, Kuwaraha KC, Prizon RC. 2018. Structural features, labor conditions and family succession in dairy production systems in Paraná State, Brazil. Cah. Agric. 27: 45004. 